\title{
Pengaruh Pupuk Organik dan Varietas Terhadap Pertumbuhan dan Hasil Tanaman Cabai Merah (Capsicum annum L.)
}

\author{
The Effect Of Organik Fertilizer and Varieties On Growth Of Red Chili Pepper \\ (Capsicum annum L.) \\ Sahrun riza ${ }^{1}$, Erita Hayati ${ }^{1}$, Ainun Marliah ${ }^{1} *$ \\ ${ }^{1}$ Program Studi Agroteknologi, Fakultas Pertanian, Universitas Syiah Kuala \\ email:sahrunriza994@gmail.com
}

\begin{abstract}
Abstrak. Cabai merah merupakan komoditas hortikultural yang termasuk golongan sayuran rempah yang termasuk famili terung-terungan dan sebagai penyedap masakan. Penelitian ini bertujuan untuk melihat pengaruh pemberian jenis pupuk organik terhadap pertumbuhan dan hasil tanaman cabai merah dan untuk melihat pengaruh varietas terhadap pertumbuhan dan hasil tanaman cabai merah serta untuk mengetahui ada tidaknya interaksi antara jenis pupuk organik dan varietas cabai merah. Penelitian ini dilakukan pada bulan Januari sampai dengan bulan Juni 2019. Penelitian ini menggunakan Rancangan Acak Kelompok (RAK) pola faktorial. Faktor yang diteliti terdiri dari dua faktor yaitu pupuk organik dan varietas. Faktor pertama jenis pupuk organik yang terdiri dari 3 taraf yaitu kontrol, pupuk kandang sapi dan pupuk kandang ayam, sedangkan faktor kedua varietas cabai merah yang terdiri dari 3 taraf yaitu Varietas TM-999, varietas Odeng dan varietas Lede Uwe gayo. Hasil penelitian menunjukkan bahwa perlakuan pupuk organik berpengaruh sangat nyata terhadap jumlah buah per tanaman dan berat buah per tanaman serta terdapat pengaruh yang nyata terhadap jumlah cabang produktif dan potensi hasil ton/ha, namun terdapat pengaruh tidak nyata terhadap tinggi tanaman umur 15, 30 dan 45 hari setelah tanam dan diameter batang umur 15, 30 dan 45 hari setelah tanam. Pemberian pupuk organik pada berat buah per tanaman dan potensi hasil terbaik diperoleh pada pemberian pupuk kandang ayam. Sedangkan perlakuan varietas berpengaruh sangat nyata terhadap jumlah cabang produktif, berat buah per tanaman dan potensi hasil, namun terdapat pengaruh yang tidak nyata terhadap tinggi tanaman umur 15, 30 dan 45 hari setelah tanam, diameter batang umur 15, 30 dan 45 hari setelah tanam dan jumlah buah per tanaman. Jumlah cabang produktif, berat buah per tanaman dan potensi hasil tanaman cabai merah terbaik diperoleh pada penggunaan varietas TM 999. Terdapat interaksi yang sangat nyata antara pupuk organik dengan varietas terhadap jumlah buah per tanaman, berat buah per tanaman dan terdapat interaksi nyata terhadap potensi hasil.
\end{abstract}

Kata kunci : Cabai Merah, Pupuk Organik, Varietas

Abstrac. Red chili is a horticultural commodity that belongs to the spice vegetable group and part of the eggplant family that is used as a food flavoring. This study aims to look at the effect of applying organic fertilizer on the growth and yield of red chili plants;to see the effect of varieties on the growth and yield of red chili plants; and to find out whether there is an interaction between types of organic fertilizer and red chili varieties. This study employed factorial randomized block design (RBD) with two factors studied namely organic fertilizer and varieties. The first factor is the type of organic fertilizer consisting of 3 levels, namely control, cow manure and chicken manure, while the second factor is red chili varieties consisting of 3 levels, namely the TM-999 variety, Odeng variety and the Gayo Lede Uwe variety. The results showed that the treatment of organic fertilizer had a very significant effect on the number of productive branches and the potential yield of tons/ha, but there was no significant effect on plant height at ages 15, 30 and 45 days after planting and stem diameter 15,30 and 45 days after planting. The fertilizer application at the fruit weight per plant and the best potential results obtained in the provision of chicken manure. Whereas, the treatment of varieties has a very significant effect on the number of productive branches, fruit weight per plant and yield potential, but there is no significant effect on plant height 15, 30 and 45 days after planting, stem diameter 15, 30 and 45 days after planting and number of fruits per plant. The number of productive branches, fruit weight per plant and the best yield potential of red chili plants were obtained from the use of TM 999 varieties. There was a very real interaction between organic fertilizer and varieties on the number of fruits per plant; fruit weight per plant; and there was a real interaction with yield potential.

Keywords:Red Chili, Organic Fertilizer, Varieties 


\section{PENDAHULUAN}

Cabai merah (Capsicum annum L.) adalah sayuran semusim yang termasuk famili terung-terungan (Solanaceae). Tanaman ini berasal dari benua Amerika, tepatnya di daerah Peru, dan menyebar ke daerah lain di benua tersebut. Di Indonesia diperkirakan cabai merah dibawa oleh saudagar-saudagar dari Persia ketika singgah di Aceh antara lain adalah cabai merah besar, cabai rawit, cabai merah keriting dan paprika. Cabai merah mengandung zat gizi yang dibutuhkan manusia seperti vitamin A, vitamin C, karoten, zat besi, kalium, kalsium, fosfor dan juga mengandung alkaloid seperti kapaicin, flavenoid, dan minyak esensial (Devi, 2010). Cabai merah tidak hanya digunakan untuk konsumsi rumah tangga sebagai bumbu masak atau bahan campuran pada berbagai industri pengolahan makanan dan minuman, tetapi juga digunakan untuk pembuatan obat-obatan dan kosmetik (Hayati et al., 2012). Produksi cabai di Indonesia masih rendah dengan rata-rata nasional hanya mencapai 5,5 ton/ha, sedangkan potensi produksinya dapat mencapai 20 ton/ha (Nurahmi et al., 2011).

Menurut Badan Pusat Statistik Kabupaten Gayo Lues (2017), produksi cabai di Kabupaten Gayo Lues tahun 2016 sebesar 6.240 ton dan ditahun 2017 mengalami penurunan sebesar 1.140 ton $(18,29 \%)$. Rendahnya produksi tanaman cabai disebabkan oleh beberapa faktor di antaranya rendahnya tingkat kesuburan tanah, dan beberapan teknik budidaya yang kurang tepat (Baharuddin, 2016). Selama ini banyak jenis pupuk yang beredar di pasaran dan memberikan hasil yang cukup baik. Akan tetapi, dari jenis pupuk yang beredar adalah pupuk anorganik yang dikenal sebagai pupuk kimia. Dalam pemakaian pupuk anorganik dalam jangka waktu yang lama memberikan hasil negatif karena pupuk kimia dapat merusak ekosistem. Untuk itu diperlukan sesuatu zat yang bukan hanya menyehatkan, tetapi juga ramah terhadap lingkungan (Nurahmi et al., 2011). Salah satu alternatif yang dapat dilakukan untuk mengatasi hal itu adalah pemberian pupuk organik.

Pupuk organik sangat berguna untuk peningkatan produksi lahan pertanian dari segi kualitas maupun kuantitas, serta mengurangi pencemaran lingkungan, dan dapat meningkatkan kualitas lahan secara berkelanjutan. Pupuk organik dalam jangka panjang dapat meningkatkan produktivitas lahan dan dapat mencegah degradasi lahan. Pemberian pupuk organik dalam jangka panjang mampu meningkatkan kandungan humus di dalam tanah, adanya humus tersebut air akan banyak terserap dan masuk ke dalam tanah, sehingga kemungkinan untuk terjadinya pengikisan tanah dan unsur hara yang ada di dalam tanah sangat kecil (Prasetyo, 2014).

Menurut Benny (2010) pupuk organik juga memiliki fungsi kimia yang penting seperti penyediaan hara makro (nitrogen, fosfor, kalium, kalsium, magnesium dan sulfur) dan hara mikro seperti zink, tembaga, kobalt, barium, mangan dan besi meskipun dalam jumlah yang kecil, meningkatkan kapasitas tukar kation tanah dan membentuk senyawa kompleks dengan ion logam yang meracuni tanaman seperti aluminium, besi, dan mangan. Selain pemupukan secara organik, penggunaan varietas juga merupakan faktor yang sangat mendukung dalam meningkatkan produksi cabai merah (Syukur at al., 2013) mengungkapkan bahwa penggunaan benih unggul bermutu mutlak diperlukan untuk meningkatkan produktivitas cabai. Penggunaan pupuk organik merupakan salah satu upaya dalam meningkatkan produksi cabai merah. Selain bermanfaat meningkatkan produksi juga memperbaiki keadaan lahan meningkatkan kandungan humus dalam tanah secara berkelanjutan. Namun seberapa besar efektivitas penggunaan pupuk organik yang dicobakan tersebut bagi pertumbuhan dan hasil beberapa varietas cabai merah belum begitu jelas.

Varietas pada cabai merah terdiri atas varietas hibrida dan varietas lokal. Varietas hibrida dapat digunakan untuk meningkatkan hasil panen karena mempunyai sifat unggul 
yang dapat bertahan terhadap serangan hama dan penyakit serta produksi yang baik dengan umur singkat. Menurut Tjahjadi (1991) varietas unggul banyak memiliki kelebihan dari varietas lokal, seperti produksi yang optimal, tingkat ketahanan terhadap organisme pengganggu tanaman, serta respon terhadap pertumbuhan. Sementara varietas lokal adalah varietas yang dibudidayakan secara turun-temurun oleh petani serta menjadi milik masyarakat dan dikuasai negara (Rostini, 2011). Menurut Andoko (2004) menyatakan bahwa varietas TM 999 mempunyai akar dan cabang sangat kuat sehingga tahan terhadap kekeringan, warna buah merah terang, ukuran daun lebih kecil, tahan terhadap layu bakteri phytoptora dan anthracnose sehingga dapat ditanam di musim hujan maupun kemarau.

Salah satu varietas unggul lokal cabai merah yang sangat dominan ditanam oleh petani di Bener Meriah yaitu cabai merah lokal yang diberi nama (Odeng). Cabai merah Odeng mempunyai potensi hasil $\pm 19-21$ ton/ha. Cabai besar Odeng dapat tumbuh subur pada dataran rendah, medium hingga dataran tinggi mencapai ketinggian 1200 meter dpl (BPTP Aceh, 2016).

Keunggulan varietas lokal (Odeng) yang tidak dimiliki varietas unggul adalah mempunyai sifat gene yang mampu bertahan terhadap kondisi cekaman biotik yang berupa hama dan penyakit tanaman bahkan dalam kondisi abiotik yang tidak menguntungkan atau tanah keracunan Besi (Fe) serta Alumunium (Al) (Daradjat at al., 2003).

Varietas Gayo Lues adalah varietas yang ditanam secara turun-temurun oleh petani yang berada di Gayo Lues, varietas ini dinamakan oleh petani sebagai Lede Uwe (Cabai Rotan) karena bentuknya yang mirip dengan rotan dengan ukuran buah yang cukup panjang dan diameter buah tidak terlalu besar, yang hampir mirip dengan bentuk rotan. Keberadaan cabai lokal gayo lues ini yang belum banyak diketahui secara luas, yang sekarang ini keadaannya sudah hampir punah dikarenakan tergantikan varietas unggul. Perlunya upaya peningkatan potensi hasil cabai lokal gayo agar masyarakat khususnya petani yang berada digalus berkeinginan membudidayakan varietas lokal tersebut, supaya tidak punah, dan sebagai aset Kabupaten, Provinsi dan Negara.

Berdasarkan uraian di atas maka dicoba penggunaan jenis pupuk organik dan beberapa varietas untuk memperkaya hara yang ada di dalam tanah, sehingga dapat meningkatkan pertumbuhan dan hasil tanaman.

\section{METODE PENELITIAN}

\section{Tempat dan Waktu Penelitian}

Penelitian ini dilaksanakan di Kampung Tampeng Kecamatan Kuta Panjang Kabupaten Gayo Lues. Penelitian ini dilakukan pada bulan Januari sampai dengan bulan Juni 2019.

\section{Bahan}

Bahan yang digunakan dalam penelitian ini adalah benih cabai merah terdiri dari tiga varietas yaitu varietas TM-999, varietas lokal Bener Meriah Odeng dan varietas lokal Gayo Lues Lede Uwe, Tanah Aluvium (Alluvial), pupuk kandang sapi sebanyak 72 kg, pupuk kandang ayam sebanyak $72 \mathrm{~kg}$ dan mulsa plastik hitam perak.

Alat

Alat yang digunakan pada penelitian ini adalah polibag persemaian, cangkul, garu, gembor, hand sprayer, ajir, talirafia, timbangan analitik, meteran kain, jangka sorong, alat tulis dan papan nama.

\section{Rancangan Percobaan}


Penelitian ini menggunakan Rancangan Acak Kelompok (RAK) pola faktorial 3x3 dengan 3 ulangan. Ada 2 faktor yang di teliti yaitu jenis pupuk organik dan varietas cabai merah.

Faktor pertama jenis pupuk organik terdiri atas 3 taraf yaitu:

$\mathrm{P}_{0}=$ Kontrol,

$\mathrm{P}_{1}=$ pupuk kandang sapi

$\mathrm{P}_{2}=$ Pupuk kandang ayam

Faktor kedua yaitu varietas cabai merah terdiri atas 3 taraf yaitu:

$\mathrm{V}_{1}=$ Varietas TM-999

$\mathrm{V}_{2}=$ Varietas Odeng

$\mathrm{V}_{3}=$ Varietas Lede Uwe

Dengan demikian terdapat 9 kombinasi perlakuan dan 3 ulangan. Secara keseluruhan menjadi 27 unit percobaan. Setiap unit percobaan terdiri atas

15 tanaman sehingga secara keseluruhan terdapat 405 tanaman. Dari setiap unit percobaan diamati 3 tanaman sampel sehingga secara keseluruhan terdapat

81 tanaman sampel. Model matematika yang digunakan untuk Rancangan Acak Kelompok (RAK) polafaktorial adalah sebagai berikut:

$\mathrm{Y}_{\mathrm{ijk}}=\mu+\beta_{\mathrm{i}}+\mathrm{P}_{\mathrm{j}}+\mathrm{V}_{\mathrm{k}}+(\mathrm{PV})_{\mathrm{jk}}+\boldsymbol{\varepsilon}_{\mathrm{ijk}}$

Dimana:

$\mathrm{Y}_{\mathrm{ijk}} \quad=$ Hasil pengamatan perlakuan pengaruh pemberian pupuk organik $(\mathrm{P})$ pada taraf ke- $\mathrm{j}$ dan penggunaan varietas $(\mathrm{V})$ pada taraf ke-k pada ulangan ke- $\mathrm{i}$

$\mu \quad=$ Rata-rata umum

$\beta_{\mathrm{i}} \quad=$ Pengaruh kelompok

$\mathrm{P}_{\mathrm{j}} \quad=$ Pengaruh pemberian pupuk organik $(\mathrm{P}) \mathrm{ke}-\mathrm{j}(\mathrm{j}=1,2,3)$

$\mathrm{V}_{\mathrm{k}} \quad=$ Pengaruh penggunaan varietas $(\mathrm{V}) \mathrm{ke}-\mathrm{k}(\mathrm{k}=1,2,3)$

$(\mathrm{PV})_{\mathrm{jk}} \quad=$ Interaksi antara pupuk organik $(\mathrm{P})$ pada taraf ke-j dengan varietas $(\mathrm{V})$ pada taraf ke-k

$\varepsilon_{\mathrm{ijk}} \quad=$ Galat

Apabila uji $\mathrm{F}$ yang menunjukkan pengaruh yang nyata, maka akan di lanjutkan dengan Uji Beda Nyata Jujur pada taraf 5\% (BNJ $\left.{ }_{0,05}\right)$, untuk membandingkan rata-rata perlakuan, rumus BNJ adalah sebagai berikut :

$\mathrm{BNJ} 0,05=\mathrm{q}_{0,05}(\mathrm{P} ; \mathrm{dbg}) \sqrt{\frac{K T G}{r}}$

Dimana:

BNJ0,05 = Beda Nyata Jujur pada level $5 \%$

q $0,05(\mathrm{p} ; \mathrm{dbg})=$ Nilai baku q yang diperoleh dari tabel pada taraf $5 \%$

$\mathrm{p} \quad=$ Jumlah perlakuan

$\mathrm{db}_{\mathrm{A}} \quad=$ Kuadrat tengah acak

KTG $\quad=$ Kuadrat tengah galat

Pelaksanaan Penelitian

$=$ Jumlah ulangan

Persiapan Benih

Benih cabai varietas TM-999 diperoleh dari Toko Sarana Produksi Pertanian Gayo Lues, varietas lokal Odeng diperoleh dari Toko Sarana Pertanian Aceh tengah/Bener Meriah, dan varietas Lede Uwe diperoleh dari masyarakat di Kecamatan Kuta panjang, Kabupaten Gayo Lues.

\section{Persemaian}


Persemaian benih cabai dilakukan dalam polibag, Media semai terdiri atas campuran tanah dan pupuk kandang dengan perbandingan 1:1.Campuran media semai yang telah dibersihkan dimasukkan kedalam polibag dan disiram sampai kapasitas lapang, lalu benih dimasukkan kedalam polibag dan ditutup tipis dengan tanah. Penyiraman dilakukan setiap pagi dan sore. Untuk menghindari sinar matahari langsung, tempat persemaian dibuat atap atau naugan.

\section{Penanaman}

Penanaman dilakukan pada sore hari, saat bibit sudah memiliki 4-6 helai daun atau sudah berumur 30 hari setelah semai (HSS). Polibag bibit dibuka, kemudian ditanam pada lubang tanam yang telah disediakan sesuai dengan perlakuan yang dicobakan.

\section{Pemupukan}

Pemupukan bertujuan untuk menyediakan sumber nutrisi bagi tanaman agar kebutuhan tanaman cabai terpenuhi. Pemberian jenis pupuk kandang dengan dosis 20 ton/ha maka didapatkan $8(\mathrm{~kg})$ per bedeng diberikan sebagai pupuk dasar. Pemupukan lanjutan menggunakan NPK (16:16:16) diberikan dengan dosis $300 \mathrm{~kg} / \mathrm{ha}$ maka didapat dosis 8 (g) per tanaman, pemupukan dengan cara pengecoran ke lubang tanam dengan konsentrasi air 200 (ml) per tanaman, diberikan sebanyak 4 kali pada umur 15 HST sebanyak 2 (g) per tanaman, 30 HST sebanyak 2 (g) per tanaman, 45HST sebanyak 2 (g) per tanaman, dan 60 HST sebanyak 2 (g) per tanaman.

\section{Pemeliharaan}

Pemeliharaan tanaman meliputi penyiraman, penyiangan, pemangkasan, pemasangan ajir dan pengendalian hama dan penyakit. Penyiraman dilakukan pada sore hari menggunakan hand sprayer, jika tidak turun hujan atau keadaan tanah terlalu kering. Penyiangan dilakukan pada sore hari dengan cara mencabuti gulma-gulma yang ada di sekitar tanaman cabai dan disamping bedeng agar tidak terjadi perebutan unsur hara antara tanaman dan gulma. Pemangkasan dilakukan sebanyak dua kali yaitu pemangkasan tunas saat tinggi tanaman telah mencapai 15-17 cm dan pemangkasan bunga pertama sekitar 35-40 HST. Pemasangan ajir dilakukan 14 HST dengan menggunakan kayu atau bambu setinggi $100 \mathrm{~cm}$ yang diikatkan pada tanaman cabai dengan menggunakan tali rafia. Pengendalian hama dan penyakit menggunakan insektisida (Decis) dengan dosis anjuran pabrik untuk tanaman cabai $(0,25 \mathrm{~m} / \mathrm{l})$ diberikan pada umur 15 HST, 30 HST dan 45 HST. Untuk mengendalikan busuk buah digunakan fungisida (Anvil) dengan dosis anjuran pabrik $(0,25 \mathrm{~m} / \mathrm{l})$ pada umur 60 dan 75 HST diaplikasikan dengan pupuk cair dengan dosis anjuran pabrik dengan cara penyemprotan ketanaman pada pagi hari sebelum jam 10 siang.

\section{HASIL DAN PEMBAHASAN}

\section{Pupuk Organik}

Hasil uji $\mathrm{F}$ pada analisis ragam menunjukkan bahwa rata-rata pengaruh jenis pupuk organik terhadap pertumbuhan dan hasil tanaman cabai merah pada peubah jumlah cabang produktif tanaman cabai merah terbanyak dijumpai pada pupuk kandang sapi, yang berbeda nyata dengan jumlah cabang produktif akibat kontrol, namun berbeda tidak nyata akibat perlakuan pupuk kandang ayam. Pada peubah jumlah buah per tanaman terbanyak terdapat pada perlakuan pupuk kandang sapi, yang berbeda nyata dengan jumlah buah per tanaman akibat perlakuan kontrol, namun tidak berbeda nyata dengan perlakuan pupuk kandang ayam. Pada berat buah per tanaman cabai paling berat terdapat pada perlakuan pupuk kandang ayam, yang berbeda nyata dengan berat buah per tanaman pada perlakuan kontrol dan pupuk kandang sapi. Pada peubah potensi hasil tanaman cabai merah tertinggi dijumpai pada 
perlakuan pupuk kandang ayam,yang berbeda nyata dengan potensi hasil akibat perlakuan kontrol, namun berbeda tidak nyata dengan potensi hasil akibat perlakuan pupuk kandang sapi. Hasil uji $\mathrm{F}$ pada analisis ragam rata-rata pengaruh jenis pupuk organik terhadap pertumbuhan dan hasil tanaman cabai merah dapat dilihat pada tabel 1.

Tabel 1. Rata-rata pengaruh jenis pupuk organik terhadap pertumbuhan dan hasil tanaman cabai merah

\begin{tabular}{lcccc}
\hline \multicolumn{1}{c}{ Peubah } & \multicolumn{3}{c}{ Perlakuan pupuk organik } & BNJ 5\% \\
\cline { 2 - 3 } & Kontrol & Sapi & Ayam & \\
\cline { 2 - 3 } Tinggi Tanaman (cm) & 9.69 & 9.08 & 9.49 & \\
15 HST & 19.4 & 17.83 & 18.51 & \\
$30 \mathrm{HST}$ & 25.66 & 23.01 & 22.82 & \\
$45 \mathrm{HST}$ & & & & \\
Diameter Batang (cm) & 0.19 & 0.18 & 0.19 & \\
15 HST & 0.33 & 0.32 & 0.36 & \\
30 HST & 0.57 & 0.48 & 0.54 & \\
45 HST & $9.88 \mathrm{~b}$ & $11.19 \mathrm{a}$ & $11.04 \mathrm{a}$ & 1.13 \\
Jumlah Cabang Produktif (cabang) & $104.86 \mathrm{~b}$ & $116.71 \mathrm{a}$ & $113.17 \mathrm{a}$ & 5.24 \\
Jumlah Buah per Tanaman (Buah) & $464.74 \mathrm{c}$ & $498.44 \mathrm{~b}$ & $523.40 \mathrm{a}$ & 20.82 \\
Berat Buah per Tanaman (g) & $12.29 \mathrm{~b}$ & $13.07 \mathrm{ab}$ & $14.06 \mathrm{a}$ & 1.31 \\
Potensi Hasil (ton ha ${ }^{-1}$ ) & & & & \\
\hline
\end{tabular}

Keterangan : Angka yang diikuti oleh huruf yang sama pada baris yang sama tidak berbeda nyata pada uji BNJ $\operatorname{taraf} 5 \%$

Hasil penelitian menunjukkan bahwa jenis pupuk organik berpengaruh nyata terhadap jumlah cabang produktif dan potensi hasil, berpengaruh sangat nyata terhadap jumlah buah per tanaman dan berat buah per tanaman. Hasil cabai merah terbaik diperoleh pada penggunaan pupuk organik kandang ayam. Menurut hasil penelitian Andayani dan La Sarido (2013), bahwa perlakuan pupuk kandang ayam memberikan produksi buah cabai merah yang lebih baik dibandingkan perlakuan pupuk kandang sapi. Hal ini diduga karena pupuk kandang ayam mencukupi nutrisi tanaman di dalam tanah, dan kadar hara pupuk kandang ayam mencukupi untuk kebutuhan tanaman serta penggunaannya lebih efektif dan efisien.

Tingginya hasil tanaman cabai yang dapat dilihat pada berat buah per tanaman dan potensi hasil akibat pupuk kandang ayam disebabkan pupuk kandang ayam mempunyai kandungan Nitrogen, Phospor, dan Kalium lebih tinggi dibandingkan pupuk kandang sapi. Menurut Tohari (2009) dalam prasetyo (2014) pupuk kandang sapi memiliki kandungan hara yang lebih besar yaitu Nitrogen sebesar $0,4 \%$, Phospor $0,2 \%$, dan Kalium 0,1\%, sedangkan pupuk kandang ayam memiliki kandungan Nitrogen sebesar 1\%, Phospor 0,8\%, dan Kalium 0,4\%. Perbedaan kandungan unsur hara ini disebabkan oleh beberapa faktor yakni jenis hewan, jenis makanan yang diberikan serta umur dari ternak itu sendiri. Menurut pendapat Musnawar (2003) dalam Tufailah et al. (2014), menyatakan bahwa pupuk kandang ayam mengandung unsur hara lengkap yang dibutuhkan oleh tanaman untuk mendukung pertumbuhan seperti unsur hara nitrogen $(\mathrm{N})$, fosfor $(\mathrm{P})$ dan kalium $(\mathrm{K})$, kalsium $(\mathrm{Ca})$, magnesium (Mg) dan sulfur (S). Selanjutnya Lingga dan Marsono (2005) menyatakan bahwa pupuk organik dapat memperbaiki struktur tanah, menaikkan daya serap tanah terhadap air, 
meningkatkan aktifitas mikro organisme di dalam tanah, dan sebagai sumber zat makanan bagi tanaman.

Perlakuan jenis pupuk organik berpengaruh tidak nyata terhadap tinggi tanaman umur 15,30 dan 45 HST, dan diameter batang umur 15, 30 dan 45 HST. Hal ini diduga karena unsur hara di dalam tanah masih cukup untuk menunjang pertumbuhan dan perkembangan tanaman. Hal ini disebabkan karena tanah yang digunakan untuk penelitian adalah tanah yang secara terus menerus menggunakan pupuk organik maupun pupuk anorganik. Menurut pendapat Hayati et al. (2012) menyatakan pemberian berbagai jenis pupuk organik pada tanaman cabai merah menghasilkan pertumbuhan yang sama pada tanaman cabai merah umur 15 HST dan 30 HST. Menurut hasil penelitian Andayani dan La Sarido (2013), bahwa pada pemberian pupuk organik yaitu kandang ayam dan sapi tidak memberikan perbedaan yang nyata pada parameter tinggi dan diameter batang cabai merah umur 15 HST. Selanjutnya Lakitan (2004), menyatakan bahwa pada awal pertumbuhan tanaman, kandungan unsur hara belum terserap oleh tanaman, selain itu pada fase pertumbuhan vegetatif, tanaman dipengaruhi oleh sifat genetik tanaman itu sendiri, sehingga pengaruh dari faktor luar tanaman tidak terlalu berpengaruh terhadap tinggi tanaman.

\section{Varietas}

Hasil uji $\mathrm{F}$ pada analisis ragam menunjukkan bahwa rata-rata pengaruh varietas terhadap pertumbuhan dan hasil tanaman cabai merah pada peubah jumlah cabang produktif tanaman cabai merah lebih banyak dijumpai pada perlakuan varietas TM-999, yang berbeda nyata dengan jumlah cabang produktif akibat perlakuan varietas Lede Uwe gayo, namun berbeda tidak nyata akibat perlakuan varietas Odeng. Pada peubah berat buah per tanaman terberat terdapat pada perlakuan varietas TM-999, yang berbeda nyata dengan berat buah per tanaman akibat perlakuan varietas Odeng dan varietas Lede Uwe gayo. Pada peubah potensi hasil tanaman cabai merah tertinggi dijumpai pada perlakuan varietas TM-999, yang berbeda nyata dengan potensi hasil varietas Odeng dan varietas Lede Uwe gayo. Hasil uji F pada analisis ragam rata-rata pengaruh varietas terhadap pertumbuhan dan hasil tanaman cabai merah dapat dilihat pada tabel 2.

Tabel 2. Rata-rata pengaruh varietas terhadap pertumbuhan dan hasil tanaman cabai merah.

\begin{tabular}{|c|c|c|c|c|}
\hline \multirow[t]{2}{*}{ Peubah } & \multicolumn{3}{|c|}{ Perlakuan Varietas } & \multirow[t]{2}{*}{ BNJ 5\% } \\
\hline & TM 999 & Odeng & Lede Uwe & \\
\hline Tinggi Tanaman $(\mathrm{cm})$ & & & & - \\
\hline $15 \mathrm{HST}$ & 9.56 & 9.42 & 9.28 & \\
\hline $30 \mathrm{HST}$ & 17.17 & 18.96 & 19.27 & \\
\hline $45 \mathrm{HST}$ & 23.38 & 24.39 & 23.72 & \\
\hline Diameter Batang $(\mathrm{cm})$ & & & & - \\
\hline $15 \mathrm{HST}$ & 0.19 & 0.19 & 0.18 & \\
\hline $30 \mathrm{HST}$ & 0.37 & 0.32 & 0.32 & \\
\hline $45 \mathrm{HST}$ & 0.56 & 0.51 & 0.52 & \\
\hline Jumlah Cabang Produktif (cabang) & $11.53 \mathrm{a}$ & $11.47 \mathrm{a}$ & $9.11 \mathrm{~b}$ & 1.13 \\
\hline Jumlah Buah per Tanaman (Buah) & 109.67 & 114.52 & 110.55 & - \\
\hline Berat Buah per Tanaman $(\mathrm{g})$ & $534.55 \mathrm{a}$ & $504.02 \mathrm{~b}$ & $448.00 \mathrm{c}$ & 20.82 \\
\hline Potensi Hasil (ton ha ${ }^{-1}$ ) & $15.09 \mathrm{a}$ & $12.93 \mathrm{~b}$ & $11.40 \mathrm{c}$ & 1.31 \\
\hline
\end{tabular}


Hasil penelitian yang telah dilakukan menunjukkan bahwa perlakuan varietas berpengaruh sangat nyata terhadap jumlah cabang produktif, berat buah per tanaman, dan potensi hasil (ton $\mathrm{ha}^{-1}$ ). Dari beberapa varietas cabai merah yang dicobakan hasil terbaik dijumpai pada varietas TM 999.

Dari tiga varietas yang digunakan dalam penelitian ini yaitu TM 999, Odeng, dan Lede Uwe Gayo, hasil terbaik untuk peubah potensi hasil (ton $\mathrm{ha}^{-1}$ ), jumlah cabang produktif, jumlah buah per tanaman, dan berat buah per tanaman dijumpai pada varietas TM 999. Hal ini diduga karena varietas TM 999 lebih unggul dari segi genotipe sehingga dapat menyesuaikan diri dengan lingkungan. Selain itu perbedaan pertumbuhan dan hasil dari setiap varietas selain berkaitan dengan genetik dari tanaman itu sendiri, tetapi juga dipengaruhi oleh faktor lingkungan, struktur maupun tekstur tanah. Hal ini sesuai dengan pendapat Hayati et al. (2012), bahwa pertumbuhan dan hasil tanaman cabai merah terbaik diperoleh pada pengaruh varietas TM-999. Selanjutnya Marliah et al. (2011) menyatakan tingginya hasil cabai merah yang diperoleh pada varietas TM 999 dan TS 168 disebabkan masing-masing varietas mempunyai perbedaan genetik, sehingga mempengaruhi pertumbuhan dan hasil, meskipun secara genetik ada varietas yang mempunyai potensi hasil tinggi, namun hasil tersebut hanya dapat tercapai setelah berinteraksi dengan lingkungan. Menurut Gardner et al. (1991) bahwa ciri-ciri tertentu dari suatu pertumbuhan dipengaruhi oleh genotipe sedangkan yang lainnya dipengaruhi oleh lingkungan. Simatupang (1997) dalam Hayati et al. (2012), menyatakan bahwa tingginya hasil suatu varietas disebabkan varietas tersebut telah mampu beradaptasi dengan lingkungannya. Faktor genotipe dan faktor lingkungan akan mempengaruhi daya genetik untuk pertumbuhan dan perkembangan tanaman.

Hal ini menunjukkan penampilan pertumbuhan vegetatif dan generatif yang berbeda antar varietas disebabkan oleh adanya perbedaan kecepatan pembelahan, perbanyakan dan pembesaran sel, serta dipengaruhi oleh faktor genetik dan lingkungan, serta perbedaan daya tumbuh antar varietas yang berbeda ditentukan oleh faktor genetiknya. Selain itu, potensi genetik dari suatu tanaman akan lebih maksimal jika didukung oleh faktor lingkunga (Khairiyah et al., 2017).

Uji adaptasi varietas diperlukan untuk mendapatkan varietas dengan kemampuan tumbuh dan produksi yang baik pada kondisi spesifik lokasi. Varietas TM 999 menghasilkan hasil lebih tinggi dibandingkan dengan varietas Odeng dan Lede Uwe Gayo. Lede Uwe Gayo daya potensi hasilnya lebih rendah karena benih tersebut merupakan benih yang belum bersertifikasi dan masih benih lokal. Lede Uwe Gayo merupakan cabai varietas lokal asli Gayo Lues yang ditanam oleh petani secara turun-temurun di ladang sebatas sebagai bumbu dapur, yang mana varietas ini dinamakan oleh para petani di Gayo Lues sebagai lede uwe.

Interaksi

Hasil penelitian menunjukkan bahwa terdapat interaksi yang sangat nyata antara pemberian jenis pupuk organik dan varietas cabai merah terhadap peubah berat buah per tanaman dan interaksi nyata pada potensi hasil (ton $\mathrm{ha}^{-1}$ ). Kombinasi antara jenis pupuk organik dan varietas terbaik dijumpai pada kombinasi pupuk kandang ayam dengan varietas TM 999 merupakan perlakuan terbaik untuk hasil tanaman cabai merah pada peubah jumlah buah per tanaman, berat buah per tanaman, dan potensi hasil (ton ha ${ }^{-1}$ ). Hal ini diduga varietas TM 999 lebih respon terhadap pemberian pupuk organik terutama pupuk organik ayam. Menurut Grace (2017), menyatakan bahwa pupuk kandang ayam memiliki unsur hara N, P dan K yang tinggi dibanding pupuk kandang sapi. 


\section{DAFTAR PUSTAKA}

Andayani dan La Sarido. 2013. Uji Empat Jenis Pupuk Kandang Terhadap Pertumbuhan Dan Hasil Tanaman Cabai Keriting (Capsicum annum L.). Sekolah Tinggi Ilmu Pertanian. Sangatta. Jurnal Agrifor. 12 (1) : 22-29.

Andoko, A. 2004.Budidaya Cabai Merah Secara Vertikultur Orga-nik. Penebar Swadaya. Jakarta. $85 \mathrm{hlm}$.

Badan Pusat Statistik. 2017. Luas Tanam, Panen dan Jumlah Produksi Tanam Cabe Besar di Kabupaten Gayo Lues Tahun 2017. Aceh.

Baharuddin, R. 2016. Respon Pertumbuhan Dan Hasil Tanaman Cabai (Capsicum annum L.) Terhadap Pengurangan Dosis Npk 16:16:16 Dengan Pemberian Pupuk Organik.v 32 (2), 115-124.

Balai Pengkajian Teknologi Pertanian Provinsi Aceh. 2016. Uji Adaptasi Cabai Merah (Capsicum annum) Varietas Lokal Aceh Dalam Upaya Pelestarian Sumber Daya Genetik (SDG) Di Beberapa Ketinggian Tempat di Provinsi Aceh. Aceh.

Benny dan Joewono. 2010. Pupuk Kandang. http://nasional.kompas. com/read/2010/11/26/20241199/tahi.ayam.ini.harganya. rp.500. Diakses Pada 22 Agustus 2018.

Daradjat, A. A., U. Susanto., B. Suprihatno. 2003. Perkembangan Pemuliaan Padi Sawah di Indonesia. Jurnal Litbang Pertanian 22 (3).

Devi, R. N. 2010. Budidaya Tanaman Cabai Merah. Tugas akhir.Universitas Sebelas Maret. Surakarta.

Gardner, F.P., R. B. Pearce dan R.L. Mitchell. 1991. Fisiologi Tanaman Budidaya.Universitas Indonesia, Jakarta. $427 \mathrm{hlm}$.

Grace, S.S.S., Yetti, H., dan Murniat. 2017. Pengaruh Pemberian Pupuk Kandang dan KCl Terhadap Pertumbuhan dan Produksi Tanaman Bawang Merah (Allium ascalonicum L.). JOM FAPERTA. 1(4) : 1-12.

Hayati, E., T. Mahmud, dan Fazil, R. 2012. Pengaruh Jenis Pupuk Organik dan Varietas Terhadap Pertumbuhan Dan Hasil Tanaman Cabai (Capsicum annum L.). Jurnal Floratek. 7: 173 - 181. Prodi Agroteknologi . Fakultas Pertanian. Universitas Syiah Kuala. Banda Aceh.

Khairiyah., Khadijah, S., Iqbal, M., Erwan, S., Norlian., dan Mahdiannoor. 2017. Pertumbuhan dan Hasil Tiga Varietas Jagung Manis (Zea mays saccharata Sturt) Terhadap Berbagai Dosis Pupuk Organik Hayati Pada Lahan Rawa Lebak. Program Studi Agroteknologi. Sekolah Tinggi Ilmu Pertanian Amuntai. Ziraa'ah. 42 (3) : 230240.

Lakitan, B . 2004. Dasar-Dasar Fisiologi Tumbuhan. PT. Raja Grafindo Persada. Jakarta.

Lingga, P, dan Marsono. 2005. Petunjuk Penggunaan Pupuk.Jakarta.Penebar Swadaya. 150 hlm

Marliah, A., Nasution, M., dan Armin. 2011. Pertumbuhan Dan Hasil Beberapa Varietas Cabai Merah Pada Media Tumbuh Yang Berbeda. Jurnal Floratek . 6: 84-91 Prodi Agroteknologi . Fakultas Pertanian. Universitas Syiah Kuala. Banda Aceh.

Nurahmi, E., T. Mahmud, dan S. S. Rossiana. 2011. Efektivitas Pupuk Organik Terhadap Pertumbuhan Dan Hasil Cabai Merah. 158 - 164 hlm.

Prasetyo, R. 2014. Pemanfaatan Berbagai Sumber Pupuk Kandang sebagai Sumber N dalam Budidaya Cabai Merah di Tanah Berpasir.v 2 (2), 125- 132. 
Rostini, N. 2011. 6 Jurus Bertanam Cabai Bebas Hama dan Penyakit. Agro Media Pustaka. Jakarta. $87 \mathrm{hlm}$.

Syukur, M., R. Yunianti, dan R. Dermawan. 2013. Sukses Panen Cabai Tiap Hari. Penebar Swadaya. Jakarta.

Tjahjadi, Nur. 1991. Bertanam Cabai.Yogyakarta. Penerbit Kanisius

Tufailah, M., D. Darmalaksana, dan D. Alam. 2014. Kotoran Ayam Untuk Meningkatkanhasil Tanamanmentimun (Cucumis sativus L.) Di Tanah Masam. Fakultas Pertanian. Universitas Halu Oleo. Kendari. Jurnal Agroteknos. 1 (2) : 120127. 